\title{
Disembodied archives: The disconnectedness of records and archives management practices within the Pietermaritzburg Cluster of Theological Libraries, KwaZulu-Natal, South Africa
}

\begin{tabular}{|c|c|}
\hline \multicolumn{2}{|c|}{$\begin{array}{l}\text { Author: } \\
\text { Francis Garaba }{ }^{1}\end{array}$} \\
\hline \multicolumn{2}{|c|}{$\begin{array}{l}\text { Affiliation: } \\
{ }^{1} \text { School of Religion, } \\
\text { Philosophy and Classics, } \\
\text { University of KwaZulu-Natal, } \\
\text { South Africa }\end{array}$} \\
\hline \multicolumn{2}{|c|}{$\begin{array}{l}\text { Correspondence to: } \\
\text { Francis Garaba }\end{array}$} \\
\hline \multicolumn{2}{|c|}{$\begin{array}{l}\text { Email: } \\
\text { garaba@ukzn.ac.za }\end{array}$} \\
\hline \multicolumn{2}{|c|}{$\begin{array}{l}\text { Postal address: } \\
29 \text { Golf Road, } \\
\text { Pietermaritzburg 3201, } \\
\text { South Africa }\end{array}$} \\
\hline \multicolumn{2}{|c|}{$\begin{array}{l}\text { Dates: } \\
\text { Received: } 12 \text { May } 2014 \\
\text { Accepted: } 12 \text { Nov. } 2014 \\
\text { Published: } 26 \text { Nov. } 2015\end{array}$} \\
\hline \multicolumn{2}{|c|}{$\begin{array}{l}\text { How to cite this article: } \\
\text { Garaba, F., 2015, } \\
\text { 'Disembodied archives: } \\
\text { The disconnectedness } \\
\text { of records and archives } \\
\text { management practices within } \\
\text { the Pietermaritzburg Cluster } \\
\text { of Theological Libraries, } \\
\text { KwaZulu-Natal, South } \\
\text { Africa', Verbum et Ecclesia } \\
36(1), \text { Art. \#1357, } 20 \text { pages. } \\
\text { http://dx.doi.org/10.4102/ } \\
\text { ve.v36i1.1357 }\end{array}$} \\
\hline \multicolumn{2}{|c|}{$\begin{array}{l}\text { Copyright: } \\
\text { (C) 2015. The Authors. } \\
\text { Licensee: AOSIS } \\
\text { OpenJournals. This work is } \\
\text { licensed under the Creative } \\
\text { Commons Attribution } \\
\text { License. }\end{array}$} \\
\hline $\begin{array}{l}\text { Read online: } \\
\text { 口ist回 }\end{array}$ & $\begin{array}{l}\text { Scan this QR } \\
\text { code with your } \\
\text { smart phone or } \\
\text { mobile device } \\
\text { to read online. }\end{array}$ \\
\hline
\end{tabular}

This article discusses the findings of a study that was conducted between February 2013 and November 2013 to determine the inter-connectedness between records and archives management practices for religious archives within the Pietermaritzburg Cluster of Theological libraries (PCTL). It is important to note that much of our national heritage is recorded in the archives of our religious institutions, hence the need to ensure that a continuum of care is provided for this Christian heritage from the point of creation to the retirement of those records with enduring value. Data for this study were obtained primarily through a selfadministered questionnaire, interviews and direct observation. The study revealed that there is much disharmony with regards to records and archives management-practices, which explains why documentary records in custody were incomplete. This incompleteness threatens the corporate memory of these institutions. An important recommendation proposed is the urgent need for archivists within these establishments to adopt a proactive stance in order to ensure that records should not only be properly managed for business continuity but that a healthy and complete record should be transferred to the repository for the benefit of posterity. Furthermore, there is a need to establish a central depository to coordinate records and archives management-activities, thus ensuring best practices in records and archives management.

\section{Introduction}

The importance of religious archives cannot be underestimated as these are amongst a nation's earliest records of identity, a source of local history. These records also hold evidence of land ownership and use, building developments and demographic composition and changes over time (Eberhard 2013). Accordingly, the guiding principle in records management is to ensure that information is available when and where it is needed, in an organised and efficient manner and in a suitably maintained environment (Presbyterian Church of Aotearoa New Zealand [PCANZ] 2010-2012).

The proper management of records ensures that the right information is with the right people at the right time (Church of England 2009). One of the consequences of the failure to manage records effectively, Mnjama and Sebina (2001) noted, is that staff waste valuable time searching for information. It follows then that the primary purpose of managing records is to meet the operational and evidential needs of the organisation to enable it to carry out its functions effectively (Church of England 2008; International Records Management Trust [IRMT] 1999). McLeod (2002) agrees and notes that records capture the actions and transactions of organisations and that they are a valuable asset. Managing them is crucial if they are to be used for evidence and if their information content, an organisation's memory, is to be effectively and efficiently exploited.

Duffy (2008) notes that, when properly created and maintained, records serve as reliable evidence of the activities and transactions of the religious institution and its agents. The Archives Council of Wales (2002) points out that the records we create today may become the archives of tomorrow only if they are allowed to accumulate in a controlled way. It therefore follows that defining records-management responsibilities as noted by Kynaston and Deserno (2005) ensures the capture of significant records and facilitates their transition to archival custody and use. Sumners (2010) and Mnjama and Sebina (2001) observe that about the only time when records management is discussed in an institution's staff meeting is when some crisis has occurred. An example could be when a file cannot be located, and the officer has been summoned to be told of his or her weaknesses and failures. 
Best (2002) expresses similar sentiments and notes that, when problems arise in the processes or accountability of the business, it is usually found that some part of the records life cycle has not been properly attended to: either files cannot be found or records are lost or have been destroyed, or all of the filing cabinets are full, and no more storage space is available. Best (2002) further notes that when documents are incomplete, it usually leads to cases where decisions cannot be recalled or a series of events cannot be reconstructed because the integrity of the record has been compromised. Unfortunately, religious institutions seldom initiate actions to manage their records in a more effective and efficient manner. Mnjama and Sebina (2001) note that many organisations are still not aware of the value that recorded information have for their business because they do not recognise that records are a valuable asset. It is a proven fact that the entire programme of a religious institution can benefit by improving control over the records it maintains and creates. Le Goff and Section of International Organizations (SIO) (2009) noted that the benefits include an informed vision of past events and transparency of information.

Records management has been defined as the systematic and administrative control of records throughout their life cycle to ensure efficiency and economy in their creation, use, handling, control, maintenance and disposition (IRMT 1999; ISO 15489-1 2001; Pearce-Moses 2005). Consequently, as noted by Yusof and Chell (2002), records management is an administrative tool which is vital to the efficient management of an organisation, and it affects every area of corporate affairs. Yusof and Chell (2002) further posit that many organisations adopt records-management practices to eliminate problems caused by the inefficient and unsystematic management of their records.

Pearce-Moses (2005) states that the activities, policies and procedures within an organisation with which it implements records management are the constituent parts of a recordsmanagement programme. In this regard, a religious' institution's records-management programme should strive to achieve economy and efficiency in the creation, use, maintenance and disposal of its records. Its basic purpose is to help answer that nagging question of what do I keep, for how long do I keep it and when can I remove it from my office (PCANZ 2010-2012). It follows that records-management programmes handle records throughout their lifecycle, especially in their active, semi-active and non-active stages (Brunskill \& Demb 2012; Kynaston \& Deserno 2005; Mnjama \& Sebina 2001). This study therefore investigated recordsmanagement practices in the seven religious organisations within the PCTL with a view of ascertaining whether there was a link between records and archives management practices within the cluster and, if not, of developing and suggesting a basic operational framework.

\section{Context of the study}

The PCTL is an association of the libraries of the Evangelical Seminary of Southern Africa (ESSA); St. Josephs Theological
Institute (SJTI); Cedara, the School of Religion, Philosophy and Classics (SRPC) at the University of KwaZulu-Natal; the Congregational House of Formation $(\mathrm{CHoF})$; the Anglican House of Studies (AnHoS); the Seith Mokitimi Methodist Seminary (SMSS) and the Lutheran Theological Institute (LTI). It should be pointed out from the onset that within some of these library institutions exist manuscript collections with a theological orientation, and as noted by Suelflow (1965), these archives are a stepchild within the library establishment.

In that light, Mnjama (2007) observed that the placement of the archives unit within the administrative structure of the library is a contentious one. Regardless of the placement, it will be argued that what is fundamental is to ensure that there is a professional person, be it an archivist or manuscript librarian, to provide a continuum of care for the records. Within the PCTL, both designation terms are used interchangeably, and at this juncture, some background on the origins of the cluster will suffice.

The idea of a cluster system can be traced back to 1987 when Dr James Cochrane joined the Department of Theology at the then University of Natal in Pietermaritzburg, South Africa. Dr Cochrane shared his experience of a cluster as encountered in Chicago in the United States of America (USA). Funding was obtained for the late Professor Wittenberg, a lecturer in Old Testament Theology and one the cluster's founders, to visit Chicago in 1988 with the view of adapting ideas relevant to the Pietermaritzburg situation (Interview with G. Wittenberg, retired professor of Old Testament Theology, University of Natal, 06 February 2013).

The clusters studied in the USA included the Association of Chicago Theological Schools (ACTS), the Boston Library Consortium and the Union Theological Seminary. ACTS is an association of theological seminaries committed to utilising resources to the maximum. The models studied in the United States were adapted to the Pietermaritzburg situation. The structure of the Pietermaritzburg cluster was set up during 1989 with the official inauguration of the cluster in March 1990. The vision statement, called Declaration of Intention was signed by local bishops and the heads of the respective institutions. It is in essence an agreement amongst the theological institutions in the area to form a cluster of theological educational institutions to work together towards the provision of a contextual theological education (Van Rooyen 1996).

\section{Background to the problem}

The urgent need for ecclesiastical records to be handled efficiently becomes paramount in today's digitally mobile society. Eberhard (2013) observes that the lack of knowledge about the collections in religious institutions in Australia and worldwide also need to be addressed as far as gathering statistics (quantity, location, dates, etc.) is concerned. She also refers to the records inventory which is one of the most important component in any records-management 
programme. The National Archives, the Archives and Records Association and the Religious Archives Group (2010) note that the archives of the future can only be formed if good recordkeeping practices are followed in relation to current records. It further notes that the systematic management of current material is necessary for the formation of an archival record which can be used to defend legal rights and support the business and other mission and promotional activities of religious organisations, particularly in terms of digital records.

The World Bank (2013) points out that, without good records keeping, officials are forced to take decisions on an ad hoc basis without the benefit of an institutional memory. In similar vein, the John Curtin Prime Ministerial Library (2004) and the Association of Canadian Archivists (2000) observe that records are society's tools for establishing facts and provide a concrete way to validate human memory. Records are an information asset which serves as evidence or proof of decisions and actions taken by individuals and organisations.

Religious institutions therefore need to be proactive in taking control of their active records to ensure that not only a healthy but a complete record gets into the archives. Thomas (2013) is in agreement with the aforesaid and notes that there is obviously a great need for the archival voice early on to ensure that the relevant material that will eventually become part of an institution's collection is not disposed of. However, evidence on the ground points to the fact that the occasional transfer of records to the archives within the cluster is not providing an accurate and thorough reflection of the organisation's activities, hence the yawning gaps with regards to the documentation in custody.

Kynaston and Deserno (2005) aptly remark that the quality of an archive's holdings depends on the effectiveness of the records-management programme responsible for the records before they reach the archives. Kaczmarek (2006) echoes similar sentiments and observes that the absence of a good records-management programme also has a bearing on the quality and integrity of the institutional archives. The 1988 conference on the threats to the Christian heritage underscored the fact that many evangelical organisations lack a sense of their history because of a poor policy of record retention (Billy Graham Centre Archives 2010).

Cox (1992) opines that the establishment of a recordsmanagement programme can also enhance the preservation of archival records before they come to the archives. The existence of a records-management programme will ensure that corporate memory is preserved by implementing policies and procedures that ensure the protection of the information held in the records. Stewart (2004:112) and Kynaston and Deserno (2005) all agree that an intrinsic connection exists between archives and recordsmanagement programmes, and they further note that, without a records-management programme that guides the organisation and a disposition of active and semiactive records, an archives programme will not receive a comprehensive, reliable and authentic body of records. Rather, it will host a miscellaneous collection of varying value and usefulness, transferred on an ad hoc basis according to individual interests, priorities and workloads.

Within religious organisations, evidence points to the fact that the concept of records management is unknown, and custodians of this Christian heritage are passive recipients. This explains the de facto neo-Jenkinsonians about which Johnson and Rankin (2006; see also Convery 2011) candidly opine that the days of a records professional as a passive curator are certainly numbered. The status quo is that organisations have no systematic or formal approaches to recordkeeping. Consequently, processes and practices are fragmented or non-existent. Cox (1992) posits that the scattered nature of religious records is aggravated by the fact that there is no records-management programme that provides for the orderly transfer of valuable records to the archives when these records' usefulness as current or active (frequently consulted) records needing to be maintained in the offices comes to an end. He (Cox 1992) further observes that a full-scale inventory needs to be completed, and the development of a records-disposition schedule should be given urgent priority. The 1988 conference's report on archives at risk further emphasises the need for archivists and records managers to inform administrators about archival needs and programmes and stresses the importance of maintaining an active, vital archive within the evangelical community (Billy Graham Centre Archives 2010). In a nutshell, as noted by Stewart (2004) and Maher (1992) a records-management programme protects the institutional memory by ensuring that the organisation's historical records are identified, retained and preserved.

In addition, there are only a few studies devoted to the records-management practices of religious organisations. With particular reference to the need for records management within religious organisations, Suelflow (1980) observes that, whilst the management and support of religious archives frequently vary as much as their objectives, scope and activities, some depositories remain in the unenviable position of serving as adjuncts to theological libraries, to officers or to boards uninterested in archives.

In his case study of the records and archives of the Roman Catholic Church in the United States, Cox (1992) reiterates, amongst other things, the need for the establishment of a records-management system that is built on a comprehensive inventory of records, a records-disposition schedule and closer collaboration with staff mostly responsible for the creation of records and use. Thornborow (2007) undertook a records management survey of the Methodist Church in the United Kingdom and whilst his study focus was limited to one institution, he correctly observes that the records of religious institutions are private and are thus less subject to legislation and inspection. Garaba (2013), in a survey of the collection stewardship of cluster repositories, recommends 
the need for more research on the records-management practices of these archival repositories.

This study therefore sought to examine whether there is a link between records and archives management in these cluster repositories and to propose a rudimentary framework for the success of a records-management programme. Shepherd and Yeo (2003:246; South African National Standard [SANS 15489-2] 2004) observe that all organisations should have a formally agreed policy for the management of their records. As noted by the Association of Commonwealth Archivists and Records Managers (ACARM) (2012), a records-management policy is a document that serves as a mandate for managing records in an organisation. It provides guidance, justification and explanation on why certain records are kept and others discarded (Congregational Library \& Archive 2010). Similarly, the Pacific Regional Branch of the International Council on Archives (PARBICA 2009) states that having a records-management policy helps staff understand the importance of managing records well and sets the broad standards that staff should follow to achieve good records management.

\section{Research questions}

The aim of the study was to examine records-management practices in the seven religious organisations within the PCTL with a view of ascertaining whether there is a link between records and archives management practices within the cluster and, if not, to develop and suggest a basic operational framework. The field survey was carried out between February and November 2013. The following research questions were pertinent to the study:

1. Is there a policy-making board overseeing the management of records within an institution?

2. Is there a records-management policy, and which aspects does it cover?

3. How does the material come into the archives?

4. Has the institution undertaken a survey in an effort to gather information about existing records?

5. What is considered to be vital records?

6. To which archival professional group(s) is the institution or individual affiliated?

7. What suggestions would augur well for the improvement of church-archives administration within the PCTL?

\section{Literature review}

The literature review revealed that very little research has been carried out in the field of records management in religious institutions. The problem is compounded by the fact that much of the literature on religious archives is obsolete, and available resources online, whilst helpful, are mostly guides or manuals for practitioners. The Records Management Journal of 2004 (Records Management Journal 2004) devotes a special issue on the records-management practices of voluntary organisations in the United Kingdom but had nothing on religious institutions. Thornborow (2007) notes that the complexity of the internal processes of religious institutions helps to explain the dearth of literature on records and archives management. Bayane (2012) reports on a survey of the Church archives in Botswana, and his study concentrates mostly on the management of archives at the non-active stage and not the active stage, which can be construed as a major limitation. Garaba (2013) studies the collection stewardship of these cluster repositories with his main focus on the non-active stage of the records. His recommendation on the need to investigate the recordsmanagement practices of these institutions did, however, instigate this research.

Mnjama and Sebina (2001) survey records-management practices within private-sector organisations but without any specific focus on religious institutions. The study's major finding is that a sound records-management programme is a prerequisite for a programme to manage the quality of systems. Records, they argue, are the lifeblood of the organisation. Furthermore, Shepherd (2006) concur and notes that, in organisations where records are not properly managed, records will often be inadequate for the purposes for which they are needed, will frequently be lost, may be destroyed prematurely and may be retained unnecessarily.

Mnjama and Sebina (2001) further note that the failure to manage records is not just a minor lapse in administrative work but a case of bad management. Their study outlines the broad areas that must be included in a sound recordsmanagement programme. Chachage and Ngulube (2006) similarly report on a study on private organisations, focusing on the Iringa region in Tanzania. They propose a model on records management which this study borrowed for the conceptual framework. The same could also be said of Ngoepe's study (2013) which, whilst proposing a model for public-records management in South Africa, was found impressive for its conceptual framework. These studies are significant in that, of late, scholars have been have been arguing for comprehensive and coordinated information policies to cater for information generated by public and private institutions in various countries. According to Chachage and Ngulube (2006), the passing of 'FOI laws' in some countries underscores the need for private records to be managed so that they will be available when citizens request to have access to them in terms of the law. Mnjama (2005:468) also notes that the private sector is yet to participate fully in the collection and preservation of records and archives. Eberhard (2013) concurs and points out that records created by private bodies or institutions exist without the benefit of legislation that mandates their creation, preservation and use. Hence the glaring disparities between private and public records.

\section{Research methodology}

In order to ascertain the link between records management and archives management within the PCTL, this study employed the survey method. No sampling was done as the target population was small. Also, Leedy (1997:277; 
Neuman 2009:106-107) suggests that there is little point in sampling populations that are smaller than 100. In such cases, one should survey the entire population. Two sets of respondents were selected, and data were primarily collected by using two self-administered questionnaires, one directed at administrators and the other at archivists or manuscript librarians (refer to Appendices 2 \& 3). To supplement the data gathered from questionnaires, faceto-face interviews and direct observations were done with archivists, manuscript librarians, deacons in parishes, pastors, lecturers on church history and administrators of the institutions under study.

A total of seven institutions were surveyed within the cluster, and the primary study population consisted of five (5) archivists or manuscript librarians working within the cluster. The secondary population consisted of seven (7) administrators also working in these institutions (refer to Appendix 1). One institution has two administrators with one working in the property-management section of the parent company offsite, and one works at the institution and is in charge of the day-to-day running of the seminary. This institution thus has two separate archival units with the archivist supposed to overseer the administration of both archives, which does not happen in practice. The choice of this population was justified in that the research sought to establish the link between records and archives management as the assumption was that manuscript librarians or archivists dealt with non-active records whilst administrators deal with active and semi-active records. Twelve (12) of the fourteen (14) questionnaires were returned, five from archivists and seven from administrators.

To help uncover potential problems in this survey instrument, pre-testing was done by a selected group of respondents from an analogous population before its deployment. The pre-testing was conducted on a panel of experts consisting of library professionals within the PMB cluster. This target population was chosen for their expertise, experience and involvement in issues pertaining to religious archives. Participants were selected on the basis of their ability to provide professional opinions concerning the instruments. Respondents for pre-testing were asked to give their views on the data-collection instrument as far as the quality of its appearance, content and length are concerned. Pre-testing the questionnaire enabled the researcher to validate the instrument by checking whether it obtained the results required and, in this instance, checking matters pertaining to the problem of records management.

This pre-testing exercise was necessary because, in constructing a questionnaire, there is always the possibility of an error (Babbie \& Mouton 2001; Dawson 2002). The questionnaire comprised 11 questions, and it was structured in such a way that it would not tire respondents as the instrument was short and tailor-made to capture the recordsmanagement aspect which was the focus of the study. The quantitative data gathered were analysed using the
Statistical Package for the Social Sciences (SPSS) as it is the most widely available statistical package for data analysis (Powell 1985:160).

\section{Ethical considerations}

The Declaration of Intention for the Pietermaritzburg Cluster of Theological Institutions provides the key to explaining ethical issues surrounding this research. All institutions that make up the cluster agreed in principle in 1990 to work together in the provision of a contextual theological education in a changing South Africa. It is in this light that this research should be viewed and whilst this study was not commissioned research, feedback to the respondents was promised in the form of a scientific report, which would give details of the findings of the research as well as direct feedback to the archival repositories as promised in the covering letter to the questionnaires used to collect the data for the study. The respondents to the questionnaires and those that participated in the observations and interviews were informed about the purpose of the research and participation was thus voluntary. With regards to security of data, the researcher ensured that this was properly stored and secured and anonymised. Research findings were presented honestly, without deliberate distortions. The outcome of this research is not likely to harm any of the respondents. If the outcomes of the study were implemented they would contribute to best practices in the management of records and archives within the cluster repositories.

\section{Trustworthiness}

The survey was carried out according to the procedures that are outlined in the preceding section on research methodology. No preconceptions or prior values shaped the results. The research used a relevant research method that was found appropriate for this study and maintained objectivity in gathering and analysing data. In addition, the research findings were presented honestly, without distortions.

\section{Data analysis and findings of the study}

This section analyses and presents the results from the data that were obtained from questionnaires, interviews and observation. Of the 14 questionnaires that were distributed, 12 were returned, representing a response rate of $86 \%$. Response rates are a big issue in survey research as authorities are not agreed on what constitutes an adequate response rate. Babbie and Mouton (2001:261) assert that a response rate of $50 \%$ is adequate for analysis whilst responses of $60 \%$ and $70 \%$ are good and very good respectively. For this research, non-respondents were ignored, and the assumption was that the missing data were thought to be similar to the data of those who did respond. It was assumed that the missing data would have little bearing on the study's results. Apparently, one of the non-responding institutions did not have an archival facility whilst, for the other institution, one 
questionnaire was returned by the archivist and not by the administrator whom the researcher found uncooperative in spite of several reminders to return the questionnaire. Quantitative data were analysed using SPSS. The results are presented according to the research questions outlined earlier on, and the presentation of this data is not tied to any specific institution as anonymity was promised during the data collection.

\section{Is there a policy-making board overseeing the management of records within an institution?}

The purpose of this research question was to ascertain the existence of this policy-making board in the surveyed institutions as having this body ensures that there is responsibility when it comes to managing the records of an institution. The respondents were asked whether their organisation had a policy-making board overseeing its records. From the administrators' side, four indicated that they had a policy-making board compared to three who did not. From the archivists' side, one out of five indicated that they had a board whilst four did not have one. Results further reflect that, whilst all seven of the surveyed organisations (100\%) acknowledged that they had in custody active records of which they were in charge on a daily basis for administrative use, the responsibility for taking control of these active records reveal some interesting findings.

From the administrators' side, the responsibility is evenly distributed with one out of seven administrators stating that the responsibility is shared between the archivist and administrator whilst one out of seven administrators also revealed that the responsibility lies solely with the archivist. One out of seven administrators acknowledged that nobody was in charge of the active records, and one also stated that it was the responsibility of the secretary. Two respondents indicated that it was the administrator's responsibility. From the archivist's side, the data reveal almost a similar pattern with two respondents stating that the responsibility for active records lies with the administrator and one stating that the responsibility was a joint effort between administrator, rector and secretary. One archivist out of five acknowledged that they were in charge of the active records together with the administrator.

\section{Is there a records-management policy and which aspects does it cover?}

Having a records-management policy helps organisations to ensure the effective management of records. The purpose of policies and procedures is to provide an environment conducive to proper records management. With this in mind, a records-management policy is a statement that describes what the organisation does and intends to do with respect to its records (ACARM 2012). According to ISO 15489-1 (2001), the objective of the policy should be the creation and management of authentic, reliable and usable records, capable of supporting business functions and activities for as long as they are required. Results indicated that, as far as the administrators are concerned, three did have a policy as compared to four who did not. Only one archivist did have a policy as compared to four without policy.

Commenting on the current state of records at one institution, this is what an archivist had to say:

Presently, many administrative records, that is, agendas, minutes, reports, financial records, student records, correspondence are listed and housed in the offices of the principal, registrar and finance. There is awareness in administration of the need to consider archiving and records management policy. This will be discussed in committee in early 2014. (Archivist, Female)

\section{How does the material come into the archives?}

A thriving records-management programme is evidenced by the transfer of records to intermediate storage when the administrative use of the records has waned. Smalley (2010) notes that a successful records-management programme provides a method and time frame for orderly transferring records that have enduring value to the archives. Three of the five archivists stated that they acquired their material into the archival repository through donations and transfers. One of the five archivists professed ignorance as to how the material came into the archives, and one stated that it was largely through donations. The donations offered ranged from individual items to the collections of deceased or retired clergy and administrators to institutional or personal archives.

As far as the administrators are concerned, asking respondents about archival awareness was deemed suitable as it gave the researcher an indication as to whether there was any synergy between the records that the administrators had in offices and those records that were in the repositories. Figure 1 shows that four $(57 \%)$ of the administrators were aware of their archives as compared to three (33\%) who were not aware.

Records management is about getting the right information to the right person at the right time. Ironically, responses to

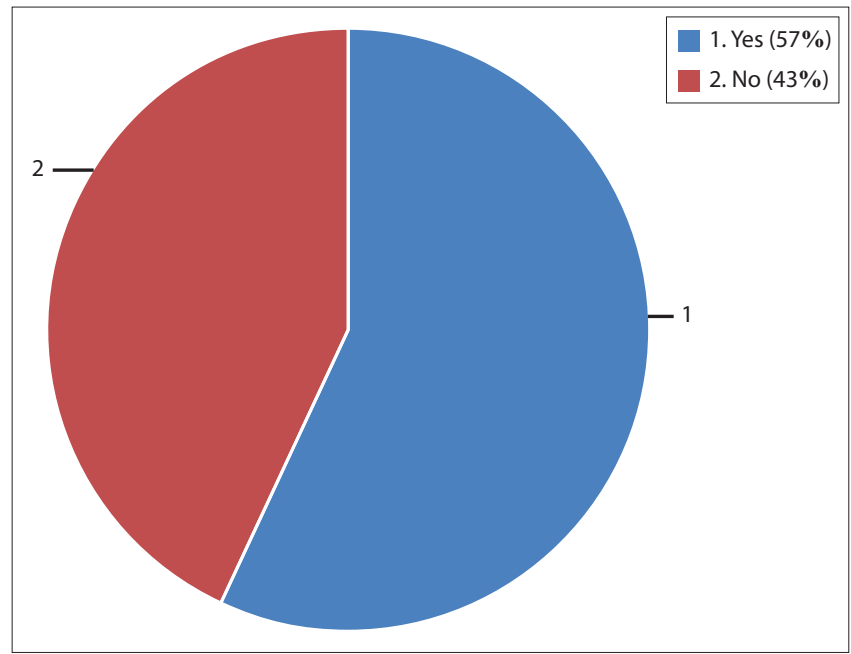

FIGURE 1: Archival awareness of administrators in the Pietermaritzburg Cluster of Theological libraries. 
the question about being able to find information from the administrators revealed that three of the seven respondents rarely had problems in retrieving information. Two respondents never had problems with finding what they wanted whilst two admitted that they often had problems in finding information. Upon verification of this data through interviews and observation, the conclusion was that this was not an honest submission from the five respondents who stated that they either rarely or never had problems with finding information as staff from other units confirmed that they had problems with administrators failing to honour financial commitments due to misplaced documentation, whether paper or electronic.

In addition, the fact that the offices are clogged with records (active, semi-active and non-active) as observed during visits points to the lack of a records-retention schedule which is crippling the efficient execution of business in an alarming way. It was also interesting to note that, as far as the administrators are concerned, only two had some formal training in records management, which covered filing, classification and retention scheduling. This is compared to five respondents who had no training. On policy pertaining to email, three administrators stated that they moved it to folders if it had permanent value whilst four administrators also stated that they printed the email together with the official reply and then filed and stored it.

\section{Has the institution undertaken a survey in an effort to gather information about existing records?}

The first step in beginning a records-management programme is to compile an inventory of what types of records an organisation has and where they are all located. Pearce-Moses (2005) remarks that this process involves surveying the records in an office, and Williams (2006) adds that this inventory is part of a records-management programme. This question was mostly directed to archivists, and from the responses received, only one institution had undertaken a survey as compared to four who have not done so.

\section{What is considered to be vital records?}

Vital records are emergency-operation records which are needed immediately to begin recovery of business after a disaster as well as rights and interests records necessary to protect the assets, obligations and resources of the organisation and its employees and customers (PearceMoses 2005 and Smith 2007). All (100\%) of the surveyed organisations confirmed that they had such records in custody and justifiably so in view of the fact that these are vital to their on-going life. The surveyed institutions were able to list the records that they deemed vital for their continued existence following an emergency. Some of the examples cited were the following: personnel records; parish registers for baptisms, confirmations, marriages and funerals; contractual agreements; minutes; student marks; admissions; study permits; timetables and prospectuses; title deeds; share certificates; statutory documents and financial records.

\section{To which archival professional group(s) is the institution or individual affiliated?}

It remains a proven fact that associations support the development of the profession, particularly in terms of capacity building. Ngulube (2005; Millar 2010) opines that the ability of archivists, librarians and curators to preserve the recorded heritage of humankind mainly lies in building partnerships and collaboration with professionals that share their concern in achieving their institutional and societal goals. From Figure 2, it is evident that the South African Preservation and Conservation group (SAPCON) was the popular choice, followed by the South African Society of Archivists (SASA). One institution was affiliated to both SASA and SAPCON with one non-affiliated.

Commenting on this local preference, one archivist noted that affiliating to professional associations outside of South Africa is cumbersome in view of the rigorous banking requirements. One archivist confirmed that he was a member of the International Council on Archives (ICA) and pointed out that, ironically, affiliating to the ICA's regional body, the Eastern and Southern Africa Regional Branch of the International Council on Archives (ESARBICA), was a nightmare due to stringent banking procedures and tardiness in communication. From Figure 2, it is discernible that, within the PCTL, there are no archivists affiliated to ESARBICA, Archival Platform and the South African Records Management Forum (SARMAF).

\section{What suggestions would augur well for the improvement of church-archives administration within the theological cluster of libraries?}

The feedback to this question was varied with responses ranging from the need to employ church archivists and hold workshops and seminars to the need for advocacy and active participation in professional associations. Only two of the seven institutions acknowledged the benefits of managing records at the point of creation in order to have a healthy record in the archive. One of these institutions acknowledged

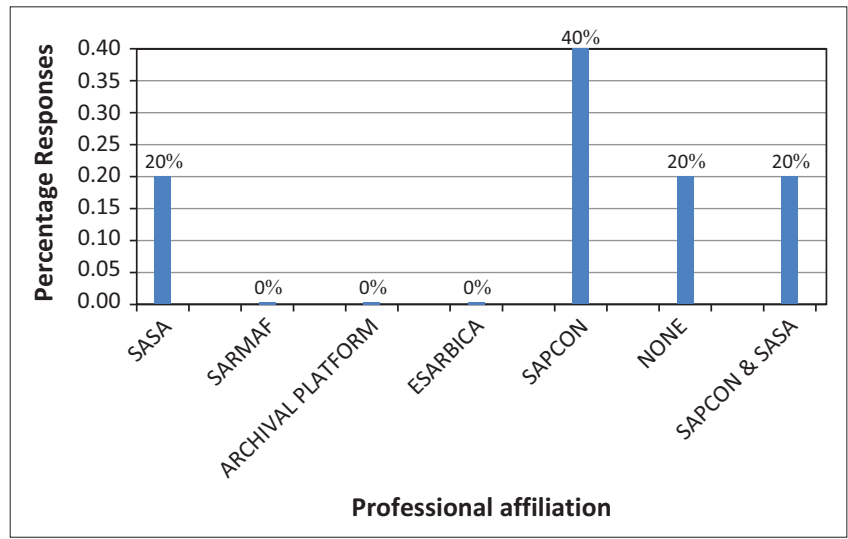

FIGURE 2: Professional affiliation. 
that their administration was aware of the need to consider an archiving and a records-management policy. There were other interesting findings that were unearthed for this question. For instance, one institution went further and noted that, based on experience at their repository, there was a need for improved access, information literacy and relevant content. These views are reproduced here verbatim. On improved access and relevant content, this comment is worth noting:

Access should not be viewed in the narrow sense of merely having archival records on the premises, but rather access in the much wider sense of enabling the archives user to access the records in order to meet personal or social needs. A major factor affecting access to information at our institution is the geographical distribution of our users (especially black), the majority of whom live outside the city centre where the archives is located. Moreover, while we have indexes, guides, catalogues and finding aids that have been produced to assist people to access records, they are all in English and generally not designed for use by people unaccustomed to research. Besides there is a fee attached to all services rendered ..., this can still constitute as a barrier to the majority of our users, who are mostly unemployed. There can be no equity of information access unless relevant and accessible content is available. A predominant amount of documents at our repository are in English and there remains a lack of content written in indigenous languages, the primary languages of many black South Africans. Further, the vast majority of information at our repository is written for an audience reading at an average or advanced literacy level, representing a major barrier for many users. (Archivist, Male)

Commenting on the need for indigenous languages to be given a voice in the intellectual field, the President and founder of the Umsamo Institute and South African Healers Association, Dr Velaphi (WO) Mkhize (2013), noted that:

\footnotetext{
... We need to launch research projects in isiZulu; make research documents available in isiZulu and cultivate and nurture the language - funds should be set aside for research projects in isiZulu ... in addition, government, legal and other significant institutional documents should be translated into African languages. (n.p.)
}

On information literacy, the following comment came from the same institution:

It is essential for the archives user to be able to locate, evaluate and use information effectively on a day to day basis. This is especially true amongst many of our black users. It must be remembered in apartheid South Africa, the decision to exclude a child from well-run schools was based solely on their race. The consequences of this educational disadvantage are very evident in the low levels of literacy many black South Africans manifest today. This can create a huge barrier to information access as proven by our experience at our repository. (Archivist, Male)

\section{Discussion of the results}

The results of the survey reveal the lack of synergy between records management and archival administration as the majority of archivists in the surveyed institutions (60\%) are passive custodians who, according to Millar (2010), wait for historical papers to arrive at their doorstep. The gravity of the matter is compounded by the fact that neither archivists nor manuscript librarians are in charge of the collection of borndigital material which means that, in the next few decades, this heritage will be lost. Keakopa (2008) notes that, without concerted efforts to deal with the management of born-digital material, significant information is bound to be lost, including the corporate memory of an institution. Hence, she appeals to archivists and records managers to be actively involved in facilitating the proper management of born-digital material as part of an organisation's recordkeeping systems.

Overall, the results reveal that there is remarkable disharmony between answers given by the administrators and those by the archivists, which points to the disconnectedness between records management and archiving. Consequently, most of the manuscripts in custody are there by accident rather than by design - orphaned archivalia to be precise because records retirement from active to no-active use is not systematic. Commenting on the transition from records to archives, Millar (2010) observes that, more often than not, archival materials travel through a complicated and circuitous route before ending up in the hands of archivists. This status quo is gravely alarming, which largely explains why the documentation in custody is incomplete and why a healthy record is not guaranteed in the archives. Ryan (2013) observes that one cannot successfully preserve records if they are not created, managed, stored and transferred properly. The enormity of the task at hand is further compounded by the internal work processes of these religious organisations, which is complex. This explains why records management activities are fragmented. The proposed model to tackle this problem might be of help (see Figure 3). Adopting a one-size fits all approach is not ideal due to the internal dynamics of these organisations.

Deutrich (1952) observed quite a while back that it is the practice amongst Lutheran churches for each parish to be responsible for its own records, and that assessment still rings true to this day. The Brief guide for archives of congregations (2002) agrees with Deutrich (1952) and comments that the primary responsibility for congregational archives rests with the congregation. Specific responsibility for maintaining the records of the congregation rests with the pastor and others involved in the creation of congregational records. Deutrich (1952) further notes that the constitution, rules or by-laws of individual congregations usually, if not always, make the preservation of records mandatory for the pastor.

For the Evangelical Lutheran Church of South Africa (ELCSA), the ELCSA constitution (2012), Chapter 2, Section 2.10 for instance, states that it is one of the duties of the pastor to keep clear and accurate records and make annual and other reports as required. In spelling out what needs to be done to minutes of meetings of the parish council, Chapter 3, Section 3.6 of the ELCSA constitution (2012) further states that the minute book shall be kept in the office of the parish. In consequence, records are usually stored in the church office, the parsonage or, in some cases, in the basement of the church. One lecturer for church history commented: 
Records are kept in the parishes and we have had cases whereby the outgoing pastor has shown reluctance to hand over the records for the new pastor which has a detrimental effect in as far as accurate records keeping is concerned. (Lecturer, Male)

One of the primary objectives of this study was to find out whether institutions have a records-management policy. According to ACARM (2012), this policy gives authority to the recordkeeping programme, outlines staff and management responsibilities and ensures that the records-management function is given due priority. Significant anecdotal evidence showed that the majority of these institutions (80\%) did not have a records-management policy. This largely explains why managing records is a big challenge. Not surprisingly, the incongruence between answers given by both the administrators and archivists points to the disconnectedness with regard to records-management practices.

From the findings, it is apparent that a records-management policy is generally lacking, and this view is supported by evidence from the literature. This confirms Gibson's (2013) experiences that records management is seen as a concept that can be 'placed' into an organisation as if it were a teapot on a breakfast table. Ngoepe and Ngulube (2013) also observe that, in view of this fact, records management is not regarded as an essential component for corporate governance. It thus remains a footnote or, better still, a forgotten function in government administration in South Africa; this equally applies to private organisations. The bottom line is that there is much myth and misunderstanding of what records management does, why it is needed and who it is really for (Gibson 2013). This absence of a comprehensive records management policy has been confirmed in the literature as one of the main causes of archival underdevelopment in Africa (Mnjama 2005; Mnjama \& Sebina 2001; Ngulube \& Tafor 2006:58), and religious institutions are no exception.

Coupled to the foregoing is the issue of records transfer. From the findings, it is clear that three $(60 \%)$ of the archival institutions acquired their material through donations and transfers. Figure 1 shows that four (57\%) in institutions are aware of archives as compared to three (43\%) that are not aware. The interesting aspect, however, is that the transfer of records to the archives is not systematic and is punctuated with inconsistences, and therefore, the record in custody is incomplete. Interviews with an archivist at one of these institutions confirmed that, since her appointment three years back, the administrator had not made a deposit of records to the archives, possibly because they still had administrative use. Also, the administrator once asked her what archives are all about. Such ignorance confirms that there is no systematic transfer of records to the archives. Interviews and observation visits to the administrative offices revealed that officers kept records in their offices, and no one but themselves knew of their existence. Not surprisingly, the offices were clogged with documents, some on the floor due to lack of space, and it was easily discernible that records management was nonexistent. The fact that officers could not timeously execute financial commitments, for instance, glaringly points to the absence of systematic disposal of records, resulting in poor retrieval of information when the need arise.

This absence of a records-management programme was also confirmed by the lack of a records survey as only one institution had undertaken the survey as compared to four who had not. Without this survey, it is difficult to come up with a records inventory to decide what types of records an organisation has and where they are located. Again, this evidently points to that disconnectedness between records management and archives management. What this means is that records are not managed from the point of creation through to ultimate disposal, and as such, a healthy record is not guaranteed in the repositories. Millar (2010) points out that, to many archivists, the ideal circumstance in which to receive archives is through a formalised and sustained management programme, ensuring continuity of care from the time that records are created and used to the time that selected records are placed in archival custody. Gold (1995) defines the records inventory as a listing of all record series, giving detailed information about each entry, including the retention period and the citation upon which the retention period is based. This basic survey of an institution's records will tell you what records are maintained, where they are located, in what quantity and how they are organised and arranged.

This overview is essential for a records-management programme, hence Gold (1995) regards it as the cornerstone to sound records-management practices. It also establishes official record titles for all files, thus preventing the costly storage of several copies of a single record under multiple titles. In making such an inventory, one will like find many records - duplicates and redundant records - which can be destroyed immediately. Gold (1995) argues that when the records inventory is in place, it enables the institution to know what they have to manage. Not only does the institution need to know what, but it also needs to know when, where, how much and, in many cases, why. Smith (2007) points out that this information audit is the first and most important step in gaining control of records and information. All (100\%) of the surveyed organisations confirmed they had vital records in custody and justifiably so in view of the fact that these are vital to their on-going life following an emergency. Interviews with archivists and administrators confirmed that they had made provision for back-up for some of these vital records as evidenced by duplicate copies and offsite storage facilities.

Professional affiliation helps in fostering best practices in records and archives management, and from the data gathered, it was evident that SAPCON was the popular choice, followed by SASA. Much still needs to be done by archivists and administrators with regards to joining these professional bodies. The data presented a snapshot of how isolated religious archivists are professionally, hence the lone-arranger tag. This situation is not surprising as archivists in these institutions work in a small archive with limited resources. Reflecting on her experiences, Zamon (2012) notes 
the challenges that lone workers face above and beyond those of their counterparts in well-staffed repositories: There are fewer opportunities for discussing practical, professional day-to-day issues, networking when budgets are tight may be infrequent and professional development through attendance at conferences and training events is comparatively rare.

With regards to suggestions for the improvement of church archives within the cluster, only two institutions acknowledged the benefits of managing records at the point of creation in order to have a healthy record in the archive. One of these institutions acknowledged awareness of their administration to consider an archiving and a records-management policy. Other interesting findings on suggestions centred on the need for improved access, information literacy and relevant content. The pertinent remarks noted underscore the need to re-figure the archive so that it reflects the current political, economic and social dispensation.

It is unfortunate that the colonial archives syndrome is still haunting archival institutions in this 21st century, and this urgently needs rectification as there is need to cultivate a postcolonial archival tradition. One of the measures that could be taken with regards to improving access could be translating the written documents into local languages though this does not guarantee access. At the recently concluded SASA conference (2013), archivists were unanimous in agreement that, once a document is translated, the authenticity of that translated document is compromised though this is a debatable view. In agreement with Reed (2013), it is my view that the bottom line is that what is needed is good, accountable, reliable information that reflects business actions, maintained with those characteristics that provide proof of processes to show what happened to the information irrespective of the translation.

Be that as it may, documenting in the local languages the reminiscences of prominent members of the church could help in this re-figuring exercise. As noted by Denis (1995:35), oral history is the only way to give the Christian people of Africa a role in the writing of their own history in view of the fact that the indigenous point of view is often ignored or distorted. The contribution of indigenous people to the mission of the church and the way they incorporated and reconstructed the Christian heritage to make it acceptable from the point of view of traditional culture are under-documented.

\section{Conclusion and recommendations}

The disconnectedness between records management and archives management within religious institutions belonging to the PCTL is evident from the results. The data gathered do not attest to any specific mention of the post of records manager as records management is fragmented with records management duties oscillating between archivist, secretary, administrator and rector. Results indicate that only one institution has an archivist who manages current records of the institution in liaison with the administrator. In view of the fact that records management is the cornerstone to the preservation of an organisation's corporate memory, the model proposed below could help in ensuring that there is coordinated work pertaining to records and archives management.

\section{Proposed records management model or framework for the cluster}

The empirical findings suggest that, in order to have a complete documentary heritage in religious archives repositories, there is a need for the effective adoption of records management as a tool. In this regard, this article, based on literature and empirical research on religious institutions within the theological cluster of libraries, provides a model that needs to be adopted in an effort to promote best practices in records and archives management. Figure 3 depicts the proposed framework for the cluster, subject to adaptation as this model is specifically for the ELCSA and the United Evangelical Church of South Africa (UELCSA) churches. However, the underlying principle is basically the same as there is need for centralised control over the records generated within each institution. What needs to be kept in mind here is that this proposed model is customisable, depending on each institution's records-management requirements.

\section{Explanation of the framework}

It is acknowledged from the onset that denominational structures vary between institutions, but what is fundamental is to have a registry within the episcopal hierarchy, that is to say, in the arch-bishop, bishop or dean's offices. The registry will be tasked with the mandate of collecting records for each diocese as required under various administrative ordinances of the diocese, and non-active records should be transferred to a centralised archival repository. In other words as noted by Arahuetes (2013), if one regulates the period for transfers to avoid the non-current arrival for fonds to the historical archives as is presently the case, it will guarantee a complete documentation of the Christian heritage. The Diocese of Bilbao in Spain has, for example, since 1997 established a system of records management for all its archives, and this model could be adopted by the cluster for its religious archives (Arahuetes 2013). In addition, such an arrangement will provide security for the records and more importantly facilitate the smooth hand-over and take-over between pastors to diffuse potentially explosive situations as the findings reported on one case.

Consequently, it is strongly recommended that duplicates be kept in parishes with originals stored in the centralised archival repositories. The centralised archival repository will thus provide information-storage and retrieval services to the staff and users. What it means in effect is that the various units within each diocese will undertake records management, bearing in mind that it is everyone's responsibility with the registry overseeing these activities to enable the identification and transfer of records with enduring value to the archives repository. Complete centralisation is not viable due to the 


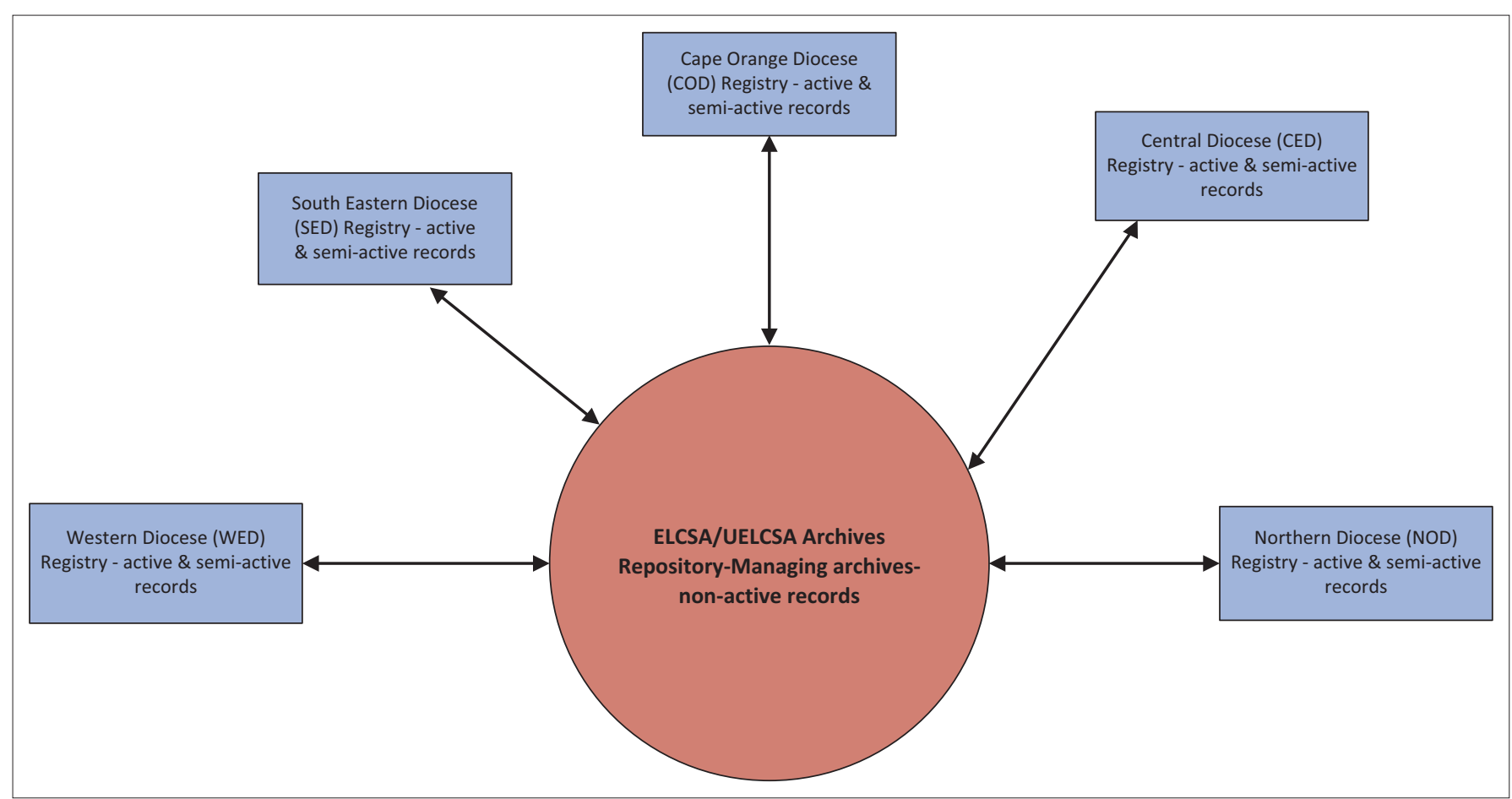

FIGURE 3: Proposed records-management model for Evangelical Lutheran Church of South Africa/United Evangelical Church of South Africa, based on the organisational structure of the churches.

fact the internal work processes or dynamics of these religious organisations are complex. As noted by Arahuetes (2013), diocesan organisms are multiple, diverse and characterised by dispersion to the extent that it is resulting in the loss and destruction of modern documentation.

The registry will take charge of entities like the generalassembly bodies, church council, arch-dioceses, dioceses, administration, circuits, parishes and congregations. Each of these units creates and keeps records, and drafting a recordsretention schedule will foster best practices in records management (see Appendix 4).

Apart from facilitating business continuity, a retention schedule reduces the storage costs associated with keeping everything. Ngoepe (2013) notes that a retention programme is also necessary to ensure the disposal of ephemeral records and to permit the transfer of records of enduring value from active maintenance to archive repositories. Similarly, Mnjama (2003) notes that scheduling records remains one of the key elements of a modern records-management programme.

Examples of records to be included in this retention schedule are minutes of parish and congregational meetings, minutes and reports of the management committee (parish council, church council, episcopal council, diocesan council, executive committee, ministerial council, etc.); minutes of all committees and groups (worship, evangelism, women's, men's, youth, Sunday school, property, etc.), selected correspondence of all committees and groups; annual reports (congregation, committees, groups); registers of baptisms, confirmations, marriages and burials; membership lists; newsletters (regular, monthly, quarterly, etc.); publications (histories, anniversaries, special occasions, brochures, service orders for special occasions); legal documents (constitutions, property titles, employment contracts); Sunday-school records (attendance rolls); photographs and audiovisual material (buildings, pastors, members, special occasions); building plans and financial records (refer to Appendix 4 for a prototype records-retention schedule).

The records mentioned above may be created and captured in a variety of formats, and it should be noted from the onset that records management should be a collective responsibility shared by all. Duffy (2008) and the Congregational Library and Archive (2010) point out that the vestry, administrators, members and employees of a congregation have a fiduciary and custodial responsibility to create and maintain an adequate record of the parish's or mission's activities. The records so created may be retained in several different formats:

- hard copy

- electronic - word processing, database, webpage

- micrographs

- computer floppies

- cd's

- photographic images

- video and audio tapes.

Weissman (2013) notes that, regardless of media, the information contained is of equal measure with regards to organisational value and the focus should be placed on the information itself and not on the medium in which it exists. Nonetheless, the application of the proposed framework should be guided by the following:

- organisation of the records

- informing staff on how to file, store and retrieve records 
- providing security for valuable records

- disposing records when they have fulfilled their legal and administrative requirements

- records follow a lifecycle

- care of records should follow a continuum.

The framework presented in Figure 3 draws heavily on the records lifecycle and continuum models to which I shall now turn. This continuum approach to managing records throughout their lifecycle, as noted by the IRMT (1999), would inter alia include the following key elements: the regulatory environment; creation and capturing records; use of records; format of the records; organisation and classification of the record collection; access and security of records; records appraisal, retention and disposal; storage of records; staffing and training; vital records management and disaster management.

Kynaston and Deserno (2005) note that the records lifecycle is a key element for both records management and archives. Consideration of the records lifecycle by both concerns ensures that only records worthy of permanent preservation are retained in the archives. Like living organisms, records have a lifecycle: they are born, live through youth and old age and then die (Shepherd \& Yeo 2003), and the three stages are as follows (Penn, Pennix \& Coulson 1994):

- a period of active use when reference is frequent and immediate access is important

- a period of storage during which the records are retained for occasional reference and for legal reasons - records scheduled for permanent retention should be identified for placement in the church archives or a permanent records storage area

- final disposition of the records, that is, their transfer to the archives or their destruction if they are no longer needed.

The Evangelical Lutheran Church of America (2010) states that it is imperative that all records flow smoothly through these three steps on a planned time schedule. If they do not, the organisation will be faced with one or more of the following problems, any of which can be a severe strain on resources (Evangelical Lutheran Church of America 2010):

- an unmanageable tangle of papers within the office

- wasted clerical effort searching for information

- loss of important operating information

- extravagant use of high-cost office space and equipment

- loss of valuable historical records through destruction or neglect.

With a well-planned records-management programme, the benefits are identified as follows in Kynaston and Deserno (2005) and Evangelical Lutheran Church of America (2010):

- identification of records of long-term historical value and their orderly transfer to the archives

- regular, orderly elimination of large amount of records that have no long-term value beyond their administrative usefulness
- speedy retrieval of information and ensuring that administrative time is not wasted waiting for needed information

- avoidance of purchasing excessive office filing equipment

- efficiency and economy in the management of the archives programme by facilitating planning regarding space, records description and records preservation.

Kynaston and Deserno (2005) identify seven key elements of a records-management programme that are important for a successful archive, and these are as follows:

- policies and procedures regarding the transfer of physical and intellectual custody of records to the archives programme; reciprocally, the archives programme must establish policy and procedures for access to records once custody has been transferred to the archives

- records-retention policy and schedules

- procedures and standards for the appraisal of records

- records-disposition procedures that ensure that destruction is authorised and adequately documented (metadata and destruction forms must be retained, especially for electronic records)

- a well-designed, documented and implemented records system that addresses these aspects:

- capture of both paper and electronic records

- records registration

- classification

- application of metadata

- storage conditions for both paper and electronic records.

- monitoring and auditing of the records management programme

- training for records creators.

It is therefore recommended that organisations have in place a records-management policy that gives authority to the recordkeeping programme, outlines staff and management responsibilities and ensures that the records-management function is given due priority. In particular, a recordsmanagement policy (ACARM 2012):

- informs staff and management of the importance of records management for the organisation, both strategically and operationally

- provides a basis for accountability

- describes in general terms responsibilities for records and, in particular, refers to the role of the records manager

- ensures compliance with relevant legislation

- provides for a records-management system to meet the organisation's business need for authentic, reliable and usable records.

To foster best practices in archives management, it might be useful to appoint an archives and records committee. This group, directly responsible to the congregation council and pastor, should primarily be concerned with providing continuous care of records as they move from active to archival status. The Brief guide for archives of congregations 
(2002) notes that the committee should develop policies regarding the archives, particularly on such issues as collection development and access to information. The committee should also learn about archival administration, seek training in archival methods whenever possible and, more importantly as noted by the Presbyterian Church of Canada archives and records office (2009), promote an awareness of the history and heritage of the congregation.

\section{Advocacy initiatives}

Wamukoya (2013) bemoans the tendency by archivists and records managers to undersell themselves, which explains why the profession is in limbo. Similarly, one of the important recommendations emphasised by the chairperson of the SASA, Prof. P. Ngulube, at the 2013 SASA conference was the need for archivists and records managers to be proactive and assertive in their own organisations so that the voice of the record has representation (Ngulube 2013). Dominy (2014) express similar remarks and notes that, as documentary lifeguards, we need to get the message about records-keeping issue across to everyone with whom we speak in our organisations. This clarion call has not been a voice in the wilderness as commenting on the blog post 'Archives \& collections on the one side; records management on the other?' on Archives Live, Trott (2013) is telepathically quoted profusely:

Even if, as archivists, you don't have the delegated responsibility (or time) to address records management in practical terms, there is still a lot of influence you can have when talking to staff in your organization about recordkeeping issues more broadly. Explain the lifecycle of records. Explain the records continuum. Bring it to life by relating it to their own work and their own concerns. Explain appraisal. The other staff are not stupid, they are just hugely busy and don't want something which will be an added workload. But if you can engage their minds and their imagination, and yes frighten them somewhat at the prospect of loss of records ... If you can get that dialogue going, and if you show an interest in their records keeping (RK) concerns as well, then you have educated an advocate for records management in the heart of the records creation process. The staff member might be the one who says; hang on, don't get rid of that without speaking with the archivist. Be an evangelist for records keeping, and get the message across everyone you speak with in your organization. I try to find an RK message in every conversation I have ... (n.p.)

It is thus discernible from the above statement that archivists and records managers need to be proactive if the voice of the record is to be heard in organisations. Gone are the days of passivity, and the perception that many archivists, especially those in religious, community or museum archives, will probably never encounter records-management programmes as noted by the Archives Association of British Columbia (1999) is not relevant anymore in this era of information abundance. Convery (2011) poignantly remarks that the real threat to the archival profession and the value of its archives comes from an ever-expanding need for stringent recordsmanagement programmes. Convery (2011) further notes that, to counter the vanishing influence in the selection of records for permanent preservation, archivists must become active within the organisation by fostering an understanding of the value of an inclusive corporate memory as an active knowledge resource. Without this assertiveness, the records and archives profession will continue in the doldrums and the inferiority complex will remain a curse that haunts archivists, rendering them professionally irrelevant in this 21st century.

\section{Acknowledgements Competing interests}

The author declares that he has no financial or personal relationship(s) that may have inappropriately influenced him in writing this article.

\section{References}

Arahuetes, A.B., 2013, 'The ecclesiastical historical archive of Biscay (AHEB-BEHA) and the ICARO Centre: A didactic resource and a challenge for interactive dissemination', ATLANTI Journal: Review of Modern Archival Theory and Practice 23(2), 23-36.

Archives Association of British Columbia, 1999, A manual for small archives, viewed 20 June 2013, from http://aabc.ca/media/6069/manualforsmallarchives.pdf

Archives Council of Wales, 2002, 'A national archives and records policy for Wales', Journal of the Society of Archivists 23(1), 7-16. http://dx.doi. org/10.1080/00379810220120528

Association of Canadian Archivists, 2000, Business archives booklet, viewed 09 September 2013, from http://www.archivists.ca/sites/default/files/Attachments/ Outreach_attachments/Business-Archives-Booklet.pdf

Association of Commonwealth Archivists and Records Managers (ACARM), 2012, ACARM records management guides: Policy/skills knowledge, viewed 03 Octobe 2013, from http://www.acarm.org/oid/downloads/6/RM\%20leaflet $\% 202$.pdf

Babbie, E. \& Mouton, J., 2001, The practice of social research, South African edn., Oxford University Press Southern Africa, Cape Town.

Bayane, S., 2012, 'A report on a survey of church archives in Botswana', viewed 21 June 2013, from http://eap.bl.uk/downloads/eap429_survey.pdf

Best, D., 2002, Effective records management - part 1: A management guide to the value of BS ISO 15849-1, British Standards Institution, London. http://dx.doi. org/10.3403/0580390071

Billy Graham Centre Archives, 2010, A heritage at risk: The proceedings of the evangelical archives conference, July 13-15, 1988, viewed 25 June 2013, from http://www2.wheaton.edu/bgc/archives/EAC/eac6.html

Brief guide for archives of congregations, 2002, viewed 30 July 2013, from http:// www.synodresourcecenter.org/admin/operations/archives/0001/guide archives_cong.html

Brunskill, C. \& Demb, S.R., 2012, Records management for museums and galleries: An introduction, Chandos Publishing, Oxford. http://dx.doi. org/10.1533/9781780632919

Chachage, B.L.M. \& Ngulube, P., 2006, 'Management of business records in Tanzania: An exploratory case study of selected companies', South African Journal of Information Management 8(3), 1-18. http://dx.doi.org/10.4102/sajim.v8i3.227

Church of England, 2008, 'Save or delete ...? The care of Diocesan records', viewed 26 June 2013, from http://www.churchofengland.org/media/51609/ careofparishrecords.pdf

Church of England, 2009, 'Keep or bin ...? The care of your Parish records', viewed 26 June 2013, from http://www.churchofengland.org/media/51609/ careofparishrecords.pdf

Congregational Library \& Archive, 2010, 'Records management for local churches', viewed 02 November 2013, from http://www.congregationallibrary.org/sites/all/ files/RecMgt2010_web.pdf

Convery, N., 2011, 'Information management, records management, knowledge management: The place of archives in a digital age', in J. Hill (ed.), The future of archives and recordkeeping: A reader, pp. 190-212, Facet Publishing, London.

Cox, R.J., 1992, Managing institutional archives: Foundational principles and practices, Greenwood Press, Westport, Connecticut.

Dawson, C., 2002, Practical research methods: A user-friendly guide to mastering research techniques and projects, How To Books Ltd., Oxford.

Denis, P., 1995, 'The use of oral sources in African church history', Bulletin for Contextual Theology in Southern Africa and Africa 2, 32-35.

Deutrich, M., 1952, 'Archival developments in the Lutheran churches in the United States', American Archivist 15(2), 127-138.

Dominy, G., 2014, 'A response to the archival platform newsletter: Reflecting on 2013: Looking forward to 2014 and on the establishment of an archival army', viewed 02 May 2014, from http://www.archivalplatform.org/

Duffy, M.J., 2008, 'Records management for congregations: A manual for episcopal parishes and missions', viewed 26 June 2013, from http://www.episcopalarchives. org/Records_Manual_for_Congregations.pdf 
Eberhard, K., 2013, 'Managing non-government records and private records in a national framework: "Religious archives" in Australia', paper presented at the Australian Society of Archivists (ASA) Conference on archives, the future, the Australian Society of
Canberra, 15-18 October.

Evangelical Lutheran Church in South Africa (ELCSA) constitution, 2012, Chapters 2 \& 3, Sections $2.10 \& 3.7$.

Evangelical Lutheran Church of America, 2010, Records management manual, viewed 20 July 2013, from http://www.elca.org/Who-We-Are/Our-Three-Expressions/ Churchwide Organization/Office-of-the-Secretary/Churchwide-OrganizationAdministration/Records-Management.aspx

Garaba, F., 2013, 'Collection stewardship constrained by resources: The management of religious archives in Pietermaritzburg, KwaZulu-Natal region', Verbum et Ecclesia: Academic Journal of the Centre for Ministerial Development 34(1), 1-11. $\mathrm{http}: / / \mathrm{dx}$.doi.org/10.4102/ve.v34i1.788

Gibson, L., 2013, 'Why care about records management?', viewed 27 August 2013 from http://rhizomedigital.com.au/why-care-about-records-management/

Gold, G., 1995, How to set up and implement a records management system, American Management Association, New York.

International Records Management Trust (IRMT), 1999, The management of public sector records: principles and context, viewed 28 June 2013, from http://www. irmt.org/documents/educ_training/public_sector_rec/IRMT_principles.pdf

ISO 15489-1, 2001, International standard: Information and documentation-records management, 1: General, Standards South Africa, Pretoria.

John Curtin Prime Ministerial Library, 2004, Overview of records and recordkeeping viewed 23 July 2013, from http://john.curtin.edu.au/society/overview/index.htm

Johnson, C. \& Rankin, M., 2006, 'Records professionals in a multimedia age: Turning lead into gold?', in A. Tough \& M. Moss (eds.), Record keeping in a hybrid environment: Managing the creation, use, preservation and disposal of unpublished information objects in context, pp. 85-105, Chandos, Oxford.

Kaczmarek, J., 2006, 'Establishing a university records management program from the inside out', Archival Issues 30(1), 23-34.

Keakopa, S., 2008, 'Management of email: A challenge for archivists and records managers in Botswana, Namibia and South Africa', Journal of the Eastern and Southern Africa Regional Branch of the International Council on Archives 27, 54-63.

Kynaston, D. \& Deserno, I., 2005, 'A records management program that works for archives', The Information Management Journal May/June, 60-62.

Le Goff, A. \& Section of International Organizations (SIO), 2009, The records of NGOs: Memory to be shared, viewed 26 June 2013, from http://www.ica.org/10105/ toolkits-guides-manuals-and-guidelines/the-records-of-ngos-memory-to-beshared. $\mathrm{html}$

Leedy, P.D., 1997, Practical research: Planning and design, 6th edn., Merrill/Prentice Hall, Upper Saddle River, New Jersey.

Maher, W.J., 1992, The management of college and university archives, The Society of American Archivists and The Scarecrow Press, Inc., Metuchen, New Jersey.

McLeod, J., 2002, Effective records management - part 2: Practical implementation of BS ISO 15489-1, British Standards Institution, London. http://dx.doi org/10.3403/0580390063

Millar, L., 2010, Archives: Principles and practices, Facet Publishing, London.

Mkhize, V., 2013, 'Mafukuzela and the remedy for the Zulu language: Sharing the riches of the language in tertiary institutions', viewed 25 September 2013, from http://www.ukzn.ac.za/news//2013/09/18/first-isizulu-john-langalibalele(mafukuzela)-dube-memorial-lecture

Mnjama, N., 2003, 'Archives and records management in Kenya: Problem and prospects', Records Management Journal 13(2), 91-101. http://dx.doi. org/10.1108/09565690310485315

Mnjama, N., 2005, 'Archival landscape in Eastern and Southern Africa', Library Management 26(8/9), 457-470. http://dx.doi.org/10.1108/01435120510631747

Mnjama, N., 2007, 'The management and administration of manuscript collections within library environments in Eastern and Southern African region', in A Mcharazo \& S. Koopman (eds.), Librarianship as a bridge to an information and knowledge society in Africa, pp. 111-120, K.G. Saur, Munchen. [(International Federation of Library Associations and Institutions ([IFLA) ] Publications 124]).

Mnjama, N. \& Sebina, P., 2001, 'Records management and private sector organizations', The African Journal of Finance and Management 9(2), 36-40. http://dx.doi.org/10.4314/ajfm.v9i2.24316

National Archives, the Archives and Records Association and the Religious Archives Group, the, 2010, Religious archives survey: $A$ survey of the archives of religious bodies within the United Kingdom and of related papers, viewed 09 June 2013 from http://www.nationalarchives.gov.uk/document/information-management/ trom ha-ras-web-17-nov.pdf

Neuman, W.L., 2009, Understanding research, Pearson Education, Inc., Boston, Massachusetts.

Ngoepe, M., 2013, 'Records management models in the South African public sector: Is there a flickering hope at the end of the dark tunnel?, paper presente at the South African Society of Archivists (SASA) Conference on archives and records management continuity in Sub-Saharan Africa, Durban, Howard College, University of KwaZulu-Natal, 10-12 July.

Ngoepe, M. \& Ngulube, P., 2013, 'An exploration of the role of records management in corporate governance in South Africa', SA Journal of Information Management 15(2), 1-8. http://dx.doi.org/10.4102/sajim.v15i2.575

Ngulube, P., 2005, 'Environmental monitoring and control at national archives and libraries in Eastern and Southern Africa', Libri 55, 154-168. http://dx.doi. org/10.1515/LIBR.2005.154
Ngulube, P., 2013, 'Chairperson's address to the South African Society of Archivists (SASA) Conference on archives and records management continuity in SubSaharan Africa', address at the South African Society of Archivists (SASA) Conference on archives and records management continuity in Sub-Saharan Africa, Durban, Howard College, University of KwaZulu-Natal, 10-12 July.

Ngulube, P. \& Tafor, V.F., 2006, 'The management of public records and archives in the member countries of ESARBICA', Journal of the Society of Archivists 27(1), 57-83. http://dx.doi.org/10.1080/00039810600691288

Pacific Regional Branch of the International Council on Archives (PARBICA), 2009, Recordkeeping for good governance toolkit, Guideline 3: Model recordkeeping policy, viewed 25 June 2013, from http://www.ica.org/11909/toolkits-guidesmanuals-and-guidelines-private-resources/the-recordkeeping-for-goodgovernance-toolkit-by-parbica.htm

Pearce-Moses, R., 2005, A glossary of archival and records terminology, viewed 26 June 2013, from http://www.archivists.org/glossary/term_details. asp?DefinitionKey $=525$

Penn, I.A., Pennix, G.B. \& Coulson, J., 1994, Records management handbook, Gower Publishing Ltd., Aldershot, Hants.

Powell, R.R., 1985, Basic research methods for librarians, Ablex, Norwood, New Jersey.

Presbyterian Church of Aotearoa New Zealand (PCANZ), 2010-2012, Records and archives management handbook for parishes and Church organizations, viewed 26 June 2013, from http://www.archives. presbyterian.org.nz/recordsmanagement2. pdf

Presbyterian Church of Canada archives and records office, 2009, Archives and records management for congregations, viewed 04 November 2013, from http://www. management for congregations, viewed 04 November
presbyterianarchives.ca/Congregational\%20RM.html

Records Management Journal, 2004, 'Special issue: Records management in the voluntary sector', Records Management Journal 14(3), n.p.

Reed, B., 2013, What does the future hold for ISO 15489?, viewed 18 November 2013 from esarbica@yahoogroups.com

Ryan, T., 2013, 'Access and freedom of information: Beyond 20 year rules, whistleblowing \& wikileaks', paper presented at the Australian Society of Archivists (ASA) Conference on archives, the future, Canberra, 15-18 October.

SANS 15489-2, 2004, Information and documentation - Records management. Part 2 Guidelines, Standards South Africa, Pretoria.

Shepherd, E., 2006, 'Why are records in the public sector organizationa assets?', Records Management Journal 16(1), 6-12. http://dx.doi. org/10.1108/09565690610654747

Shepherd, E. \& Yeo, G., 2003, Managing records: A handbook of principles and practice, Facet Publications, London.

Smalley, M.L., 2010, An archival primer: A practical guide for building and maintaining an archival program, viewed 20 July 2013, from http://www.library.yale.edu/div/ spc/archivalprimer.pdf

Smith, K., 2007, Public sector records management: A practical guide, Ashgate Publishing Limited, Aldershot.

Stewart, P., 2004, 'Records management', in D. Wythe (ed.), Museum archives: An introduction, pp. 112-119, The Society of American Archivists, Chicago, Illinois.

Suelflow, A.R., 1965, 'Preserving church historical resources', The American Archivist 28(2), 239-246

Suelflow, A.R., 1980, Religious archives: An introduction, Society of American Archivists, Chicago

Sumners, B., 2010, Records management in the church, viewed 09 June 2013, from http://www.sbhla.org/art_rec_mang.htm

Thomas, B., 2013, Archives and collections on the one side; records management on the other?, viewed 09 September 2013, from http://archiveslive.ning.com/ profiles/blogs/archives-collections-on-the-one-side-records-management-on-the

Thornborow, P., 2007, 'Non-conformist records management in Great Britain: A review', Records Management Journal 17(3), 169-178. http://dx.doi.org/10.1108/ review', Records Man

Trott, L., 2013, Archives and collections on the one side; records management on the other? , viewed 09 September 2013, from http://archiveslive.ning.com/profiles/ blogs/archives-collections-on-the-one-side-records-management-on-the

Van Rooyen, K.M., 1996, 'A performance evaluation of the Pietermaritzburg Cluster of Theological Libraries (PCTL) in order to determine whether it meets the demands of its users', Master of Information Studies dissertation, School of Human and Social Studies, Information Studies Programme, University of Natal.

Wamukoya, J., 2013, 'Reflections on African archives: Their role towards meeting the needs of society in the 21st century', paper presented at the second annua lecture on archives and records management of the Department of Information Science, UNISA, Pretoria, 14 November.

Weissman, S., 2013, Managing information as an asset, viewed 27 August 2013, from http://archiveslive.ning.com/profiles/blogs/managing-information-as-an-asset

Williams, C., 2006, Managing archives: Foundations, principles and practice, Chandos Publishing, Oxford. http://dx.doi.org/10.1533/9781780630892

World Bank, 2013, Why records management? Records management as a key support for development effectiveness, viewed 23 July 2013, from http://web.worldbank. org/WBSITE/EXTERNAL/EXTABOUTUS/EXTARCHIVES/0, ,contentMDK:20033283 pagePK:36726 piPK:437378 theSitePK:29506,00.html

Yusof, Z.M. \& Chell, R.W., 2002, 'Towards a theoretical construct for records management', Records Management Journal 12(2), 55-64. http://dx.doi. org/10.1108/09565690210442926

Zamon, C., 2012, The lone arranger: Succeeding in a small repository, Society of American Archivists, Chicago, Illinois. 


\section{Appendix 1: List of surveyed institutions}

1. Anglican House of Studies (AnHoS) The Diocese of Natal

Private Bag 899, Pietermaritzburg 3200, South Africa

Tel.: +27333941567

Fax: +27333456335

Website: http://www.anglican-kzn.org.za

2. Evangelical Seminary of Southern Africa (ESSA) 189 Pine Street, PO Box 2400, PMB 3200, South Africa Tel.: +2733 3941679

Fax: +27333940034

Website: http://www.essa.ac.za

3. Lutheran Theological Institute (LTI) 29 Golf Road, Scottsville 3201, Pietermaritzburg Tel/fax: +27332606069

Website: http://www.lti.org.za

4. Saint Joseph's Theological Institute (SJTI), Cedara Private Bag 6004, Hilton 3245, Pietermaritzburg Tel.: +27333423293

Fax: +27333435938

Website: http://www.sjti.ac.za
5. Seith Mokitimi Methodist Seminary (SMMS) PostNet Suite\#235, Private Bag X6, Cascades, PMB 3202 Tel.: 0338468600

Fax: 0338468620

Website: http://www.smms.ac.za

6. Congregational House of Formation (CHoF) c/o School of Religion, Philosophy \& Classics (SRPC) University of KwaZulu-Natal

Private Bag X01, Scottsville, Pietermaritzburg

Tel.: 0332605560

Fax: 0332605858

Website: http://www.srpc.ukzn.ac.za

7. School of Religion, Philosophy \& Classics (SRPC) University of KwaZulu-Natal Private Bag X01, Scottsville, Pietermaritzburg Tel.: 0332605560 Fax: 0332605858

Website: http://www.srpc.ukzn.ac.za 


\section{Appendix 2: Pietermaritzburg cluster archival repositories}

A questionnaire for collecting data concerning the records-management practices of religious institutions within the Theological Cluster of Institutions in Pietermaritzburg, KwaZulu-Natal, South Africa

\section{A. Institutional information}

1. Institution/church

Name

1.1 Contact person and details

\section{B. Records management}

2. Records are deemed active when reference is frequent and immediate access is important.

Do you have such records at your institution?

Yes [ ] No [ ]

3. Who is taking care of your active records at your archives or institution?

a) Administrator

b) Nobody

c) Rector

d) Secretary

e) Archivist

f) Records manager

4. Do you have a policy-making board responsible for the general oversight of records within your institution?

5. If you answered 'Yes' in 4 above, do you have a records-management policy?

6. Which aspects of records management does your policy cover?

a) Inventory of existing records (what records are maintained, where they are located, in what quantity and how they are organised and arranged)

b) Develop Record Retention Schedules (record schedules specify how long each type of record is to be held in the office for active reference, in the records centre or records storage area for semi-active reference and when it may be destroyed or transferred to the archives or some other location for permanent retention)

7. How does the material come into your archives?

a) Donations

Yes [ ] No [ ]

b) Transfer

Yes [ ] No [ ]

c) Loan

Yes [ ] No []

d) Purchase

Yes [ ] No [ ]

e) Other, please explain

8. How often do you NOT find what you want (please tick)?

O Never

O Rarely

O Sometimes

Often

Constantly 
9. The records survey (also known as a records inventory or audit) provides a picture of the records and information structure of an agency and how the records are, or should be, managed. It is a comprehensive and systematic gathering of information about records created and received by an agency (IRMT 1999). Have you at any time undertaken a survey of your institution's records in an effort to gather information about existing records?

Yes [ ] No []

10. What do you consider to be your vital records? Vital records typically document delegation of authority and lines of succession and include legal documents and contracts and financial records and other documents that establish the rights and obligations of the organisation, its employees and customers, stockholders and citizens (Pearce-Moses 2005).

11. To which archival professional group(s) are you affiliated? (Tick the ones that apply to you or your organisation)

a) South African Society of Archivists (SASA)

Yes [ ] No [ ]

b) South African Records Management Forum (SARMAF)

Yes [] No []

c) Archival Platform

Yes [ ] No []

d) Eastern and Southern Africa Regional Branch of the International Council on Archives (ESARBICA)

Yes [] No []

e) South African Preservation and Conservation Group (SAPCON)

Yes [] No []

f) None

Yes [ ] No []

g) Other, please explain

12. What suggestions would you make for the improvement of church archives within the theological cluster of libraries?

a) Employ church archivists

b) Advocacy campaigns, like holding an archives day for the cluster

c) Churches establishing their own archive institutions

d) Active participation in professional associations

e) Managing records at the point of creation in order to have a healthy record in the archives.

f) Conducting seminars or workshops at the archives or institution to raise awareness on the importance of records.

g) Other, please specify

13. Kindly provide any relevant information that might pertain to this survey.

\section{Thank you so much}

Siyabonga 


\section{Appendix 3: PMB cluster administrators}

A questionnaire for collecting data on the records-management practices of religious institutions within the Theological Cluster of Institutions in Pietermaritzburg, KwaZulu-Natal, South Africa

\section{A. Institutional information}

\section{Institution/church}

Name

1.1 Contact person and details

\section{B. Records management}

2. Records are deemed active when reference is frequent and immediate access is important.

Do you have such records at your institution?

3. Who is taking care of the active records at your archives or institution?

a) Administrator

b) Nobody

c) Rector

d) Secretary

e) Archivist

f) Records manager

4. Do you have a policy-making board that is responsible for the general oversight of records within your institution?

6. Which aspects of records management does your policy cover?

a) Inventory of existing records (what records are maintained, where they are located, in what quantity and how they are organised and arranged)

b) Develop Record Retention Schedules (record schedules specify how long each type of record is to be held in the office for active reference, in the records centre or records storage area for semi-active reference and when it may be destroyed or transferred to the archives or some other location for permanent retention) Yes [ ] No [ ]

c) Store the records conveniently and in the proper environment (efficient and proper storage) Yes [ ] No [ ]

7. How often do you NOT find what you want (please tick one only)?

O Never

O Rarely

O Sometimes

O Often

C Constantly

8. What do you consider to be your vital records? Vital records typically document delegation of authority and lines of succession and include legal documents and contracts and financial records and other documents that establish the rights and obligations of the organisation, its employees and customers, stockholders and citizens (Pearce-Moses 2005). 
9. What do you do with official email?

O Log it and delete, if it has short-term value

Move it to folders if it has permanent value

Print it together with my official reply, file it and store it

10. Have you received any form of training in records management?

11. If you answered 'Yes' in 10 above, which aspects of training were covered?

O Filing

Classification

Drafting records-retention schedules

O Records survey

None of the above, please explain below

Thank you so much

Siyabonga 


\section{Appendix 4: Records-retention schedule for religious records}

The following records-retention schedule serves as a guide. It is neither comprehensive nor tailored to fit the specific requirements of particular congregations.

\begin{tabular}{|c|c|c|}
\hline Record title or series (in alphabetical order) & Minimum retention & Retention recommendation \\
\hline Act of Incorporation & $P$ & Permanent \\
\hline Audit reports & $\mathrm{P}$ & Permanent \\
\hline Building plans and drawings & $P$ & $\begin{array}{l}\text { Retain as-built drawings, architect's renderings, and } \\
\text { renovation drawings. Transfer Mylar copies or e-copies } \\
\text { of all original drawings to parish archives and make } \\
\text { duplicate use copies. }\end{array}$ \\
\hline Bank statements & 7 & Destroy after 7 years \\
\hline Committee minutes and records & $\mathrm{P}$ & Permanent \\
\hline Compensation schedules, salary and benefit guidelines & $\mathrm{AU}$ & Destroy after use ceases \\
\hline Development and fundraising campaign records & SR & $\begin{array}{l}\text { Selective retention. Retain donor lists, case statements, } \\
\text { correspondence, minutes and planning documents. } \\
\text { Destroy receipts, letters of acknowledgement. }\end{array}$ \\
\hline Employment taxes, contributions and payments, including taxes & 7 & Destroy after 7 years (confidential record) \\
\hline $\begin{array}{l}\text { E-mail correspondence (email): executive administrative, policy } \\
\text { and programme planning, official communication and statements, } \\
\text { minutes, press releases, etc. }\end{array}$ & SR & $\begin{array}{l}\text { Review for selective retention with the following } \\
\text { guidelines in mind. } \\
\text { Permanent. }\end{array}$ \\
\hline Events files & SR & $\begin{array}{l}\text { Selective retention. Transfer to archives for final } \\
\text { review. }\end{array}$ \\
\hline Financial statements, annual & $\mathrm{P}$ & Permanent \\
\hline Financial statements, monthly & 2 & Destroy after $\mathrm{CY}+2$ years \\
\hline Grant proposals: successful applications & SR & $\begin{array}{l}\text { Selective retention. Retain proposal, final report and } \\
\text { substantive correspondence. }\end{array}$ \\
\hline Grant proposals: denied applications & 1 & Destroy after $\mathrm{CY}+1$ year \\
\hline Injury reports & 6 & Destroy after $\mathrm{CY}+6$ years after settlement of all claims \\
\hline Inventories of property and equipment, with photographs & $P$ & $\begin{array}{l}\text { Retain until superseded by new version. Place a } \\
\text { back-up copy in separate buildings or sites. Retain old } \\
\text { versions and photographs in parish archives. }\end{array}$ \\
\hline $\begin{array}{l}\text { Journals, general and special } \\
\text { funds }\end{array}$ & $\mathrm{P}$ & Permanent \\
\hline Journals, payroll & 7 & Destroy after 7 years \\
\hline Lists and schedules of subscribers or donors & $\mathrm{P}$ & Permanent \\
\hline Loan schedules & $\mathrm{AU}$ & Retain for life of loan \\
\hline Minutes of meetings & $\mathrm{P}$ & $\begin{array}{l}\text { Permanent. Keep on permanent paper or in redundant } \\
\text { electronic recordkeeping systems. }\end{array}$ \\
\hline Mortgage deeds & $\mathrm{P}$ & $\begin{array}{l}\text { Permanent. Keep in archives or comparable place of } \\
\text { safe keeping. }\end{array}$ \\
\hline Newsletters and bulletins & $\mathrm{P}$ & Permanent. Keep in archives. \\
\hline Parish sacramental registers & $\mathrm{P}$ & Permanent \\
\hline Paid bills & 7 & Destroy after 7 years \\
\hline Sermons & SR & $\begin{array}{l}\text { Selective retention. Retain full sermons for review; } \\
\text { keep printed sermons as part of an archival series. } \\
\text { Destroy sermon notes and duplicates. }\end{array}$ \\
\hline Service books and registers & $\mathrm{P}$ & Permanent. Transfer to archives \\
\hline Trust fund registers & $\mathrm{P}$ & Permanent \\
\hline Workers compensation claims and filings & 7 & $\begin{array}{l}\text { Destroy } 7 \text { years after filing or settlement of claims } \\
\text { whichever occurs later }\end{array}$ \\
\hline
\end{tabular}

Source: Adapted from Duffy, M.J., 2008, 'Records management for congregations: A manual for episcopal parishes and missions', viewed 26 June 2013 , from http://www.episcopalarchives.org/ Records_Manual_for_Congregations.pdf

P, permanent retention for purposes of indefinite legal or administrative use or archival preservation; AU, retain record for its on-going administrative use and destroy only after all current use ceases; SR, retain for selective review of individual files for permanent retention in the parish archives; CY, current year. 